\title{
PENGARUH TINGKAT PENDIDIKAN ORANG TUA, PENGHASILAN ORANGTUA, DAN MINAT BELAJAR MAHASISWA TERHADAP PRESTASI MAHASISWA JURUSAN MANAJEMEN FAKULTAS EKONOMI STAMBUK 2014 UNIVERSITAS HKBP NOMMENSEN
}

\author{
Aurora Elise Putriku 1)* \\ 1) Fakultas Ekonomi, Universitas Negeri Medan \\ *Penulis korespondensi: putri_aurel@yahoo.com
}

\begin{abstract}
Penelitian ini bertujuan untuk mengetahui pengaruh tingkat pendidikan orangtua, penghasilan orangtua dan minat belajar mahasiswa terhadap prestasi belajar mahasiswa Jurusan Manajemen Fakultas Ekonomi stambuk 2014 Universitas HKBP Nommensen. Penelitian ini dilakukan di Universitas HKBP Nommensen dengan sampel sebanyak 121 mahasiswa. Instrumen pengumpulan data dalam penelitan ini adalah observasi, dokumentasi dan angket (kuesioner). Teknik analisis data yang digunakan antara lain: uji normalitas, uji linearitas, uji multikolonieritas, uji heterokedastisitas, analisis linear berganda, koefisien determinasi dan uji hipotesis yaitu: uji t dan uji F. Hasil penelitian ini menunjukan bahwa terdapat pengaruh signifikan dari tingkat pendidikan orangtua, penghasilan orangtua dan minat belajar mahasiswa terhadap prestasi belajar mahasiswa Jurusan Manajemen Fakultas Ekonomi stambuk 2014 Universitas HKBP Nommensen baik secara parsial dan simultan.
\end{abstract}

Kata Kunci : Tingkat Pendidikan Orangtua, Pendapatan Orangtua, Minat Belajar Mahasiswa, Prestasi Belajar

Mahasiswa. 


\section{PENDAHULUAN}

Pendidikan merupakan suatu proses menyiapkan individu untuk mampu menyesuaikan diri dengan perubahan lingkungan. Pendidikan mempunyai peran penting untuk membentuk sumber daya manusia yang berkualitas dalam mencapai pembangunan nasional. Perkembangan kemajuan bangsa berada pada generasi muda yang berpendidikan dan berprestasi yang diharapkan mampu menghadapi persaingan global. Jalur pendidikan dibedakan menjadi dua, yaitu formal yang diperoleh melalui lembaga pendidikan (sekolah), dan nonformal yang diperoleh dalam bentuk pelatihan di luar pendidikan formal, misalnya kursus.

Pendidikan dimaksudkan untuk membentuk manusia secara utuh, membentuk pribadi yang dewasa, beriman dan bertakwa, mandiri, berilmu, dan bertanggung jawab, serta membentuk manusia sebagai agen pembaharuan sosial sehingga dapat menghadapi dan menyesuaikan dan mengantisipasi masa depan.

Adanya minat dalam diri seseorang akan mendorong dirinya untuk melakukan suatu tindakan dan partisipasi di dalamnya. Begitu juga dengan melanjutkan pendidikan ke perguruan tinggi, minat siswa akan mendorong mereka untuk berusaha memasuki perguruan tinggi karena mereka ingin mengembangkan ilmu dan pengetahuan.

Minat menurut Sardiman (2011:76) diartikan sebagai suatu kondisi yang terjadi apabila seseorang melihat ciri-ciri atau arti sementara situasi yang dihubungkan dengan keinginan-keinginan atau kebutuhankebutuhannya sendiri. Oleh karena itu, apa yang dilihat seseorang sudah tentu akan membangkitkan minatnya sejauh apa yang dilihat itu mempunyai hubungan dengan kepentingannya sendiri.

Minat dipengaruhi oleh beberapa faktor, antara lain faktor dorongan yang berasal dari dalam (berhubungan dengan jasmani dan psikologis) dan faktor dari luar (keluarga dan sekolah). Tindakan adalah segala kegiatan yang dilakukan oleh individu untuk mencapai keinginan dan kepentingannya. Seseorang yang mempunyai dan menaruh minat pada suatu hal akan berusaha untuk melakukan tindakan untuk mencapai hal itu.

Berdasarkan pengamatan dan pengalaman selama survei pendahluan sebelumnya, ditemukan bahwa prestasi
NIAGAWAN Vol 7 No 1 Maret 2018

mahasiswa akan dipengaruhi oleh tingkat pendidikan orangtua, penghasilan orangtua, dan minat mahasiswa. Pandangan orangtua tentang pendidikan anaknya cenderung berbeda-beda.

\section{TINJAUAN PUSTAKA \\ PENDIDIKAN ORANGTUA}

Menurut Fuad Ihsan (2003:5), pendidikan dapat diartikan sebagai:

1. Suatu proses pertumbuhan yang menyesuaikan dengan lingkungan;

2. Suatu pengarahan dan bimbingan yng diberika kepada anak dalam pertumbuhannya;

3. Suatu usaha sadar untuk menciptakan suatu keadaan atau situasi tertentu yang dikehendaki oleh masyarakat;

4. Suatu pembentukan kepribadian dan kemampuan anak dalam menuju kedewasaan.

Menurut Undang-undang No. 20 Tahun 2003 Pasal 14 tentang Sistem Pendidikan Nasional Bab I Ketentuan Umum Pasal 1 yang dimaksud pendidikan adalah: usaha sadar dan terencana untuk mewujudkan suasana belajar dan proses pembelajaran agar peserta didik secara aktif mengembangkan potensi dirinya untuk memiliki kekuatan spiritual keagamaan, pengendalian diri, kepribadian, kecerdasan, akhlak mulia, serta keterampilan yang diperlukan dirinya ,masyarakat, bangsa, dan Negara.

Menurut Dewantara (dalam Reni, 2016:2) "Pendidikan yaitu tuntutan didalam hidup tumbuhnya anak-anak itu, agar mereka sebagai manusia dan sebagai anggota masyarakat dapatlah mencapai keselamatan dan kebahagiaan setinggi-tingginya",

Kemudian Mickleright (dalam Sianipar, 2014: 9) menegaskan bahwa tidak mudah untuk melakukan generalisasi sejauh mana pentingnya pendidikan orang tua untuk kemampuan kognitif siswa. Pendidikan orangtua memberikan stimulus yang baik terhadap dukungan akademik dimana orangtua menginginkan anaknya menempuh pendidikan yang sama atau melebihi mereka.

\section{Jalur Pendidikan dan Jenis-jenis Sekolah}

1. Jalur pendidikan sekolah .

Dalam Undang-undang Republik Indonesia Nomor 2 Tahun 1989, jenis pendidikan yang termasuk jalur pendidikan sekolah terdiri dari :

a. Pendidikan umum. 
b. Pendidikan kejuruan

c. Pendidikan luar biasa

d. Pendidikan kedinasan

e. Pendidikan keagamaan

f. Pendidikan Akademik

g. Pendidikan frofesional

\section{Jalur pendidikan luar sekolah}

Jalur pendidikan luar sekolah adalah pendidikan yang diselenggarakan diluar sekolah melalui kegiatan belajar mengajar yang tidak harus berjenjang dan berkesinambungan. Pendidikan keluarga merupakan bagian dari jalur pendidikan luar sekolah yang diselenggarakan dalam keluarga dan memberi keyakinan agama, nilai budaya, nilai moral dan keterampilan.

\section{Jenjang Pendidikan}

Jenjang pendidikan nasional secara jelas dan terperinci telah diuraikan dalam Undangundang Republik Indonesia Nomor 20 Tahun 2003 tentang Pendidikan Nasional Pasal 17-19 menyebutkan bahwa jenjang pendidikan terdiri atas pendidikan dasar, pendidikan menengah dan pendidikan tinggi.

a. Pendidikan dasar

b. Pendidikan Menengah.

c. Pendidikan tinggi

Munir (Sitohang 2015: 24) menyatakan perbedaan antara orangtua yang berpendidikan tinggi dan orangtua yang berpendidikan rendah dalam hal :
a. Memberi nasehat
b. Motivasi

Demikian halnya Ahmadi (2007: 226227) berpendapat bahwa faktor - faktor biologis dan psikologis dari ayah ibu bagi anak menentukan kondisi dan kualitas kepada anaknya. Jadi dalam hal ini jelas dinyatakan bahwa kondisi dan kualitas seorang anak khususnya dalam hal kecerdasan dipengaruhi oleh kualitas orang tua mereka terutama pendidikan formal orangtua tersebut.

Wilis (2011: 9) juga berpendapat bahwa pendidikan menentukan perilaku seseorang. Orang yang berpendidikan lumayan baik akan tampak pada sikap, ucapan, dan pergaulannya ',
NIAGAWAN Vol 7 No 1 Maret 2018

\section{PENGHASILAN ORANGTUA}

Penghasilan adalah uang yang diterima dan diberikan kepada subjek ekonomi berdasarkan prestasi-prestasi yang diserahkan yaitu berupa pendapatan dari profesi yang dilakukan sendiri atau usaha perorangan dan pendapatan dari kekayaan. Disini dapat diartikan penghasilan orangtua adalah seluruh penghasilan yang diterima oleh seseorang baik yang berasal dari keterlibatan langsung dalam proses produksi atau tidak, yang dapat diukur dengan uang dan digunakan untuk memenuhi kebutuhan bersama maupun perorangan pada suatu keluarga dalam satu bulan.

Menurut Ahmad (2007:137) "Pendapatan adalah jumlah seluruh penerimaan yang diterima masyarakat yang benar-benar sampai ke masyarakat." Gie (dalam Eryanto, 2013:52) menyatakan bahwa "Income atau pendapatan adalah seluruh penghasilan seseorang baik berupa uang maupun barang yang diperolehnya untuk suatu jangka waktu."

Menurut BPS (dalam Eryanto, 2013:23) "Pendapatan adalah menunjukkan jumlah seluruh uang yang diterima oleh seseorang atau rumah tangga selama jangka waktu tertentu (biasanya satu tahun), pendapatan/ penghasilan terdiri dari upah, penerimaan tenaga kerja, pendapatan dari kekayaan seperti sewa, bunga dan dividen serta pembiayaan transfer atau penerimaan dari pemerintah seperti tunjangan sosial atau asuransi pengangguran"

\section{Penggolongan Penghasilan}

Menurut Sumardi dalam (Afiati, 2013: 64), penghasilan dapat digolongkan menjadi :

1. Penghasilan berupa uang, adalah semua penghasilan berupa uang yang sifatnya reguler dan diterima sebagai balas jasa atau kontraprestasi.

2. Penghasilan berupa barang, adalah semua penghasilan yang sifatnya reguler dan diterimakan dalam bentuk barang

3. Diluar penerimaan uang dan barang. Penerimaan ini misalnya penjualan barang-barang yang dipakai, pinjaman uang hasil undian, warisan, penagihan piutang dan lain-lain

Pembagian penghasilan yaitu :

1. Penghasilan pokok, yaitu penghasilan yang tiap bulan diharapkan diterima, penghasilan ini diperoleh dari pekerjaan utama yang bersifat rutin.

2. Penghasilan sampigan, yaitu penghasilan yang diperoleh dari 
pekerjaan diluar pekerjaan pokok, maka tidak semua orang mempunyai penghasilan sampingan.

3. Penghasilan lain-lain, yaitu penghasilan yang berasal dari pemberian pihak lain, baik bentuk barang maupun bentuk uang, penghasilan bukan dari usaha.

Dari pengertian diatas, dapat dimaksud penghasilan adalah sesuatu yang diperoleh tiaptiap individu dari bekerja atau berusaha yang dapat berupa uang, barang dan penerimaan lainlain. Dalam hal ini, uang saku yang diberikan oleh orangtua kepada mahasiswa bukan hanya berasal dari gaji/upah yang didapatkan dari pekerjaan pokok orang tua, tetapi bisa saja dari penghasilan sampingan ataupun bahkan karena pemberian.

\section{Indikator Penghasilan Orangtua}

Besarnya penghasilan seseorang dapat dilihat dari jenis pekerjaan, pendidikan, dan keahlian yang dimilikinya (dalam mendapatkan penghasilan diluar pekerjaan tetap, jumlah tanggungan dalam keluarga, serta kemampuan orangtua dalam memenuhi segala kebutuhan anggota keluarganya (Muttaqim, 2014: 35).

\section{MINAT BELAJAR MAHASISWA}

Syah (dalam Indah 2015: 25) menyatakan bahwa: "minat (interest) berarti kecenderungan dan kegairahan yang tinggi atau keinginan yang besar terhadap sesuatu".

Menurut Kamisa (dalam Khairani, 2011:176) minat diartikan sebagai kehendak, keinginan, atau kesukaan. Slameto (dalam Khairani, 2013:143) menyatakan bahwa: "berdasarkan penelitian psikologi, kurangnya minat belajar dapat mengakibatkan kurangnya rasa bidang ketertarikan pada suatu bidang tertentu, bahkan dengan melahirkan sikap penolakan terhadap guru".

Khairani menyatakan bahwa : minat dan perhatian belajar mempunyai hubungan yang erat sekali. Seseorang yang menaruh minat pada pelajaran tertentu,biasanya cenderung memperhatikan mata pelajaran tersebut bila seseorang menaruh perhatian secara kontinyu baik secara sadar maupun tidak sadar pada objek tertentu biasanya dapat membangkitkan minat pada objek tertentu.

Sedangkan yang menjadi indikator minat belajar menurut Winkel (2008:8) adalah sebagai berikut
NIAGAWAN Vol 7 No 1 Maret 2018

a. Perhatian terhadap pelajaran

b. Kesenangan terhadap pelajaran

c. Keinginan untuk belajar.

d. Dorongan untuk belajar

e. Ketertarikan mendalami pelajaran

Selanjutnya menurut Brown (Simorangkir 2016: 22) ada beberapa ciri-ciri yang mempunyai minat belajar, yakni :

1. Tertarik pada mata pelajaran

2. Tertarik pada guru

3. Mempunyai antusias yang tinggi

4. Tekun dalam mengerjakan tugas dan soal

5. Ingin selalu bergabung dengan kelompok belajar

Sedangkan menurut Bernad (Khirunnisa, 2013 :26) bahwa "minat tidak timbul secara tibatiba (spontan), melainkan timbul akibat dari partisipasi, pengalaman, kebiasaan pada waktu belajar".

\section{Faktor-faktor yang Mempengaruhi Minat Belajar}

Minat yang ada pada diri sendiri dapat timbul karena adanya faktor-faktor yang mempengaruhi dirinya. Menurut Surya (Fiorida, 2015 : 25) bahwa faktor -faktor yang mempengaruhi minat belajar siswa adalah :

1. Faktor yang bersumber dari diri siswa itu sendiri

2. Faktor yang bersumber dari lingkungan keluarga dan masyarakat

3. Suasana lingkungan sekolah. Faktor yang bersumber dari lingkungan keluarga dan masyarakat berkaitan dengan lingkungan hidup.

Menurut Loekmono dalam Khairani (2011:146), secara umum ada 5 faktor yang mempengaruhi minat belajar siswa yaitu :

1. Faktor siswa

2. Faktor orangtua

3. Faktor guru

4. Faktor lingkungan

5. Faktor ekonomi

\section{Upaya Meningkatkan Minat Belajar}

Menurut Slameto (dalam Khairani 2011:144), Minat sebagai salah satu aspek psiklogis dipengaruhi oleh beberapa faktor, baik yang sifatnya dari dalam (internal) maupun dari luar (eksternal). Dilihat dari dalam siswa, dipengaruhi oleh cita-cita, kepuasan, kebutuhan, bakat dan kebiasaan. Sedangkan bila dilihat dari faktor luarnya minat sifatnya tidak menetap 
melainkan dapat berubah sesuai dengan kondisi lingkungan. Faktor luar tersebut dapat berupa kelengkapan sarana dan prasaran, pergaulan dengan orangtua dan presepsi masyarakat terhadap suatu objek serta latar belakang sosial budaya.

Laekmono, (dalam khairani 2011: 145) mengatakan bahwa: "Minat belajar membentuk sikap akademik tertentu yang bersifat sangat pribadi pada setiap siswa, oleh karena itu, minat belajar harus ditumbuhkan sendiri oleh masingmasing siswa. Pihak lainnya hanya memperkuat dan menumbuhkan minat atau untuk memelihara minat yang telah dimiliki seseorang .

Kemudian Menurut Sudarmono (dalam Khairani 2011: 146) Minat berkaiatan dengan nilai-nilai tertentu, oleh karena itu, merenungkan nilai-nilai dalam aktivitas belajar sangat berguna untuk membangkitkan minat, misalnya belajar agar lulus ujian, menjadi juara, ahli dalam salah satu ilmu, memenuhi rasa ingin tahu mendapatkan gelar atau memperoleh pekerjaan.dengan demikian minat belajar tidak perlu berangkat dari nilai atau motivasi yang muluk-muluk. Bila minat belajar didapatkan pada gilirannya akan menumbuhkan konsentrasi atau kesungguhan dalam belajar .

Beberapa langkah untuk menimbulkan minat belajar yaitu :

1. Mengarahkan perhatian pada tujuan yang hendak dicapai

2. Mengenai unsur-unsur permainan dalam aktivitas belajar

3. Merencanakan aktivitas belajar dan mengikuti rencana itu

4. Pastikan tujuan belajar saat itu misalnya: menyelesaikan PR atau laporan

5. Dapatkan kepuasan setelah menyelesaikan jadwal belajar

6. Bersikaplah positif didalam menghadapi kegiatan belajar

7. Melatih kebebasan emosi selama belajar

\section{PRESTASI MAHASISWA}

Prestasi mahasiswa atau prestasi akademik dapat diartikan sebagai hasil pelajaran yang diperoleh dari kegiatan belajar disekolah atau perguruan tinggi yang berifat kognitif dan biasanya ditentukan melalui pengukuran dan penilaian, keberhasilan prestasi akademik mahasiswa selama mengikuti pendidikan diperguruan tinggi dinilai dari penilaian mata kuliah, penilaian semester, penilaian akhir program studi. Tolak ukur yang dipakai dalam prestasi akademik mahasiswa adalah indeks prestasi mahasiswa ( IPK)".

Menurut Winkel (2004: 36) bahwa: "Prestasi belajar siswa adalah suatu bukti keberhasilan atau kemampuan seseorang siswa dalam usaha melakukan kegiatan belajarnya sesuai dengan bobot yang dicapainya". Selanjutnya Hamalik (dalam Sianturi, 2014:20) menyatakan bahwa: "Prestasi belajar adalah suatu hasil belajar yang dicapai dari suatu perbuatan belajar". Proses belajar mengajar selalu dikaitkan dengan prestasi sebagai hasil dari perbuatan belajar.

Fungsi dari prestasi belajar siswa adalah untuk mengetahui kemajuan siswa setelah melakukan kegiatan proses belajar mengajar, dalam hal ini prestasi belajar adalah hasil yang dicapai sebagai ukuran tingkat pencapaian tujuan belajar yang telah ditentukan. Prestasi belajar siswa adalah sebagaimana yang telah digambarkan dinyatakan dengan indeks prestasi kumulatif.

\section{Peran Orangtua Terhadap Prestasi Mahasiswa.}

Menurut Rusdie (Sianturi, 2014 : 21) mengatakan bahwa agar anak didik menjadi sosok yang berprestasi dalam semua sisi kehidupan mereka, maka ada baiknya orangtua memperhatikan beberapa hal yang harus dilakukan yaitu sebagai berikut:

a. Menjadikan rumah sebagai sekolah utama.

b. Mengarahkan anak belajar secara teratur.

c. Memberikan bimbingan belajar.

d. Jangan terlalu banyak menuntut dari anak.

\section{Faktor Faktor Yang Mempengaruhi Prestasi Belajar}

Menurut Slameto (2010: 54) prestasi belajar sebagai hasil yang ingin dicapai dari proses aktivitas belajar yang dipengaruhi oleh beberapa hal yaitu :

1. Faktor internal yaitu faktor yang ada di dalam diri individu yang sedang belajar yang terdiri dari dua bagian yaitu :

a. Faktor biologis (faktor yan bersifat jasmaniah)

b. Faktor fsikologis (faktor yang bersifat rohaniah)

2. Faktor ekstern ialah faktor yang ada diluar individu yang terdiri dari : 
a. Faktor lingkungan keluarga

Faktor masyarakat dan keadaan lingkungan

\section{METODE PENELITIAN}

Penelitian ini menggunakan pendekatan survei. Singarimbun dan Effendy (1995: 8) menyatakan bahwa: survei merupakan penelitian yang mengambil sampel dari satu populasi dengan menggunakan kuesioner sebagai alat pengumpulan data yang pokok dan secara umum menggunakan metode statistik.

Jenis penelitian ini adalah deskriptif kuantitatif. Nazir (2005: 54) menyatakan bahwa: penelitian deskriptif adalah metode dalam meneliti status sekelompok manusia, suatu sistem pemikiran, ataupun suatu kelas peristiwa pada masa sekarang yang bertujuan untuk membuat deskripsi, gambaran, atau lukisan secara sistematis, faktual dan akurat mengenai fakta-fakta, sifat-sifat, serta hubungan antarfenomena yang diselidiki. Sedangkan Arikunto (2006:13), menyatakan bahwa: penelitian kuantitatif memiliki kejelasan unsur yang dirinci sejak awal, langkah penelitian yang sistematis, menggunakan sampel yang hasil penelitiannya diberlakukan untuk populasi, memiliki hipotesis jika perlu, memiliki desain jelas dengan langkah-langkah penelitian dan hasil yang diharapkan, memerlukan pengumpulan data yang dapat mewakili, serta ada analisis data yang dilakukan setelah semua data terkumpul.

Penelitian ini termasuk jenis penelitian ex-post facto, yaitu penelitian tentang variabel yang kejadiannya sudah terjadi sebelum penelitian dilaksanakan (Arikunto, 2010: 17). Penelitian ini menggunakan pendekatan kuantitatif karena menggunakan data kualitatif yang diangkakan.

Penelitian ini juga merupakan penelitian korelasional. "Penelitian korelasional adalah penelitian yang bertujuan untuk mengetahui ada tidaknya hubungan dari suatu fenomena, dan kalau ada berapa besar derajat hubungannya, antara beberapa variabel yang diteliti, walaupun tidak dapat diketahui apakah hubungan tersebut adalah hubungan sebab akibat atau bukan" (Ismani dkk, 2010:2).

Populasi dalam penelitian ini adalah seluruh mahasiswa jurusan manajemen fakultas ekonomi stambuk 2014 Universitas HKBP Nommensen" yang bejumlah 121 mahasiswa.

Penelitian ini dilakukan di Universitas HKBP Nommensen, Fakultas Ekonomi Jurusan
NIAGAWAN Vol 7 No 1 Maret 2018

Manajemen yang beralamat di jalan Jalan Sutomo No. 4A Medan-20234. Penelitian ini dilaksanakan pada semester genap tahun ajaran 2016/ 2017. Sedangkan sampel dalam penelitiana ini penulis mengambil seluruh populasi yang dijadikan sampel yaitu sebanyak 121 mahasiswa dengan teknik total sampling. Teknik pengumpulan data: observasi, dokumentasi, dan angket. Angket merupakan teknik pengumpulan data yang dilakukan dengan cara memberi seperangkat pertanyaan atau pernyataan tertulis kepada responden untuk menjawab: tingkat pendidikan orangtua, penghasilan orangtua, minat belajar mahasiswa, dan prestasi belajar mahasiswa diambil dari angket yang disebarkan langsung kepada responden (Menurut Sugiono, 2012:199). Sedangkan Uji Instrumen Penelitian digunakan Uji Validitas Angket dan Uji Realibilitas Angket.

Untuk Uji Asumsi Klasik digunakan Uji Normalitas, Uji linearitas, Uji Heteroskedastisitas, Uji Multikolinearritas. Sedangkan Teknik Analisis data dalam penelitian ini menggunakan Uji Regresi linear Berganda, Rumus uji Parsial (Uji t), Rumus uji simultan (Uji F).

\section{HASIL DAN PEMBAHASAN}

\section{Pengaruh Tingkat Pendidikan orangtua Terhadap Prestasi Belajar Mahasiswa}

Dari hasil penelitian diketahui bahwa secara parsial tingkat pendidikan orangtua memiliki pengaruh positif terhadap prestasi belajar mahasiswa mahasiswa jurusan manajemen fakultas ekonomi stambuk 2014 Universitas HKBP Nommensen. Hal ini dapat dilihat dari hasil uji-t yang menunjukkan nilai thitung sebesar 2,461 dengan harga signifikan $0,016<0,05$. Adanya tingkat pendidikan orangtua akan mempengaruhi prestasi mahasiswa., selanjutnya melalui persamaan regresi yaitu $\mathrm{Y}=25,262+0,212 \mathrm{X} 1+0,156 \mathrm{X} \_2$ $+0,623 \times 3$ artinya tingkat pendidikan orangtua memberikan kontribusi positif terhadap prestasi belajar mahasiswa mahasiswa jurusan manajemen fakultas ekonomi stambuk 2014 Universitas HKBP Nommensen.

Namun, tidak menutup kemungkinan bahwa sedikit anak yang latar belakang orang tua tingkat pendidikannya rendah memiliki tekad, untuk tidak sama dengan keadaan orang tua, keinginan dan motivasi yang tinggi untuk dapat melanjutkan pendidikan diperguruan 
tinggi serta mendapatkan prestasi yang tinggi dengan penuh harapan kelak menjadi orang yang memiliki pendidikan tinggi, serta memiliki kualitas yang bagus sebagai jalan menuju kesuksesan.

Semangat dan motivasi yang tinggi berasal dari keadaan yang terpuruk karena hidup dalam miskin ilmu yang pada akhirnya membatasi ruang gerak dalam memenuhi kebutuhan.

\section{Pengaruh Tingkat Penghasilan Orangtua Terhadap Prestasi Belajar Mahasiswa}

Dari hasil penelitian diketahui bahwa secara partial tingkat penghasilan orangtua memiliki pengaruh positif terhadap prestasi belajar mahasiswa mahasiswa jurusan manajemen fakultas ekonomi stambuk 2014 Universitas HKBP Nommensen. Hal ini dapat dilihat dari hasil uji-t yang menunjukkan nilai thitung sebesar 3,916 dengan harga signifikan $0,000<0,05$. Adanya tingkat penghasilan orangtua akan mempengaruhi prestasi belajar mahasiswa belajar mahasiswa jurusan manajemen fakultas ekonomi stambuk 2014 Universitas HKBP Nommensen. Hal ini disebabkan apabila semakin tingi tingkat penghasilan orangtua akan lebih mudah dalam membiayai dan mencukupi segala kebutuhan anak terlebih dalam melaksanakan pendidikan anak, sehingga hal ini mempengaruhi prestasi belajar mahasiswa mahasiswa jurusan manajemen fakultas ekonomi stambuk 2014 Universitas HKBP Nommensen, selanjutnya melalui persamaan regresi yaitu $\mathrm{Y}=25,262+$ $0,212 \mathrm{X} 1+0,156 \mathrm{X} \_2+0,623 \mathrm{X} 3$, artinya tingkat penghasilan orangtua memberikan kontribusi positif terhadap prestasi belajar mahasiswa jurusan manajemen fakultas ekonomi stambuk 2014 Universitas HKBP Nommensen.

Namun tidak disangka bahwa sebagian anak lainnya yang serba kekurangan menjadikan kondisi yang serba kekurangan akibat kondisi orang tua ini sebagai batu loncatan untuk lebih giat belajar dan mendapatkan prestasi belajar yang baik, memiliki motivasi yang tinggi untuk tetap melanjutkan pendidikan hingga keperguruan tinggi dan memiliki cita-cita besar untuk memerangi kemiskinan dengan harapan kelak mampu mengubah perekonomian mereka kelak.
NIAGAWAN Vol 7 No 1 Maret 2018

\section{Pengaruh Minat Belajar Mahasiswa Terhadap Prestasi Belajar Mahasiswa}

Dari hasil penelitian diketahui bahwa secara partial minat belajar mahasiswa memiliki pengaruh positif terhadap prestasi belajar mahasiswa jurusan manajemen fakultas ekonomi stambuk 2014 Universitas HKBP Nommensen. Hal ini dapat dilihat dari hasil uji-t yang menunjukkan nilai thitung sebesar 6,423 dengan harga signifikan $0,000<0,05$ yang berarti minat belajar mahasiswa akan mempengaruhi prestasi belajar mahasiswa jurusan manajemen fakultas ekonomi stambuk 2014 Universitas HKBP Nommensen. Hal ini disebabkan apabila semakin tingi minat belajar mahasiswa akan lebih meningkatkan rasa senang / rasa ketertarikan, perhatian serta dorongan untuk belajar oleh mahasiswa secara terus-menerus, sehingga hal ini mempengaruhi prestasi belajar mahasiswa, selanjutnya melalui persamaan regresi yaitu $\mathrm{Y}=25,262+0,212 \mathrm{X} 1+0,156 \mathrm{X} \_2$ $+0,623 \mathrm{X} 3$ artinya minat mahasiswa memberikan kontribusi positif terhadap prestasi belajar mahasiswa jurusan manajemen fakultas ekonomi stambuk 2014 Universitas HKBP Nommensen.

Pengaruh Tingkat Pendidikan Orangtua (X1), Tingkat Penghasilan Orangtua (X2), dan Minat Belajar Mahasiswa (X3) Terhadap Prestasi Belajar Mahasiswa (Y)

Dari hasil penelitian diketahui bahwa secara simultan tingkat pendidikan orangtua, pendapatan orangtua, dan minat belajar mahasiswa berpengaruh positif terhadap prestasi belajar mahasiswa jurusan manajemen fakultas ekonomi stambuk 2014 Universitas HKBP Nommensen. Hal ini dapat dilihat dari uji $F$ yang menunjukkan nilai Fhitung sebesar 6,618 sedangkan Ftabel $=4,86$ dengan taraf signifikan $0,000<0,05$. Hal ini berarti hipotesis keempat diterima yaitu bahwa terdapat pengaruh tingkat pendidikan orangtua, pendapatan orangtua, dan minat belajar mahasiswa terhadap prestasi belajar mahasiswa jurusan manajemen fakultas ekonomi stambuk 2014 Universitas HKBP Nommensen.

Berdasarkan hasil penelitian pada persamaan regresi linier berganda, maka diperoleh persamaan regresinya yaitu $\mathrm{Y}=$ $25,262+0,212 \mathrm{X} 1+0,156 \mathrm{X} \_2+0,623 \mathrm{X} 3+\mathrm{e}$ Dari hasil uraian di atas dapat disimpulakan bahwa tingkat pendidikan orangtua, penghasilan orangtua dan minat belajar mahasiswa 
berpengaruh terhadap prestasi belajar mahasiswa jurusan manajemen fakultas ekonomi stambuk 2014 Universitas HKBP Nommensen.

Persentasi sumbangan pengaruh variabel independen atau bebas yaitu tingkat pendidikan, pendapatan orangtua dan minat mahasiswa terhadap variabel dependen yaitu prestasi mahasiswa sebesar $68,2 \%$ sedangkan sisanya sebesar 31,8\% dipengaruhi oleh variabel lain di luar analisis terhadap variabel dalam penelitian ini.

\section{KESIMPULAN DAN SARAN}

Berdasarkan hasil penelitian dan uji statistik serta pembahasan pada Bab IV maka dapat ditarik kesimpulan sebagai berikut:

1. Persamaan regresi berganda $Y=25,262+$ $0,212 X_{1}+0,156 X_{2}+0,623 X_{3}$ yang berarti menunjukkan nilai konstanta (a) sebesar 25,262, artinya jika Tingkat Pendidikan Orangtua $\left(\mathrm{X}_{1}\right)$, Tingkat Penghasilan Orangtua $\left(\mathrm{X}_{2}\right)$ dan Minat Belajar Mahasiswa $\left(\mathrm{X}_{3}\right)$ sebesar nol, maka Prestasi Belajar Mahasiswa (Y) diperoleh sebesar 25,262. Kemudian nilai koefisien Tingkat Pendidikan Orangtua $\left(b_{1}\right)$ sebesar 0,212, artinya apabila Tingkat Pendidikan Orangtua $\left(\mathrm{X}_{1}\right)$ mengalami kenaikan sebesar satu persen, maka Prestasi Belajar Mahasiswa (Y) akan mengalami peningkatan sebesar 0,212 persen dengan syarat variabel bebas lainnya bernilai konstan. Sedangkan jika nilai koefisien Tingkat Penghasilan Orangtua $\left(b_{2}\right)$ adalah 0,156, artinya jika Tingkat Penghasilan Orangtua $\left(\mathrm{X}_{2}\right)$ mengalami kenaikan sebesar satu persen, maka Prestasi Belajar Mahasiswa (Y) akan mengalami peningkatan sebesar 0,156 persen dengan syarat variabel bebas lainnya bernilai konstan. Begitu juga halnya dengan nilai koeifisien Minat Belajar Mahasiswa ( $\left.b_{3}\right)$ adalah sebesar 0,623, artinya jika Minat Belajar Mahasiswa $\left(\mathrm{X}_{3}\right)$ mengalami kenaikan sebesar satu persen, maka Prestasi Belajar Mahasiswa (Y) akan mengalami peningkatan sebesar 0,623 persen dengan syarat variabel bebas lainnya bernilai konstan.

2. Variabel Tingkat Pendidikan Orangtua $\left(X_{1}\right)$ berpengaruh positif dan signifikan terhadap Prestasi Belajar Mahasiswa (Y) yang dapat dilihat dari nilai nilai $t_{\text {hitung }}>\mathrm{t}_{\text {tabel }}(2,461>$ $1,661)$ dan nilai signifikasi $(0,016<0,05)$.
NIAGAWAN Vol 7 No 1 Maret 2018

3. Variabel Tingkat Pendapatan Orangtua $\left(\mathrm{X}_{2}\right)$ memiliki pengaruh yang positif dan signifikan terhadap Prestasi Belajar Mahasiswa (Y) Hal ini dapat dilihat dari nilai $t_{\text {hitung }}>\mathrm{t}_{\text {tabel }}(3,5216>1,661)$ dan nilai signifikasi $(0,001<0,05)$.

4. Variabel Minat Belajar Mahasiswa $\left(\mathrm{X}_{3}\right)$ memiliki pengaruh yang positif dan signifikan terhadap Prestasi Belajar Mahasiswa (Y). Hal ini dapat dilihat dari nilai $t_{\text {hitung }}>\mathrm{t}_{\text {tabel }}(6,423>1,661)$ dan nilai signifikasi $(0,004<0,05)$.

5. Dari hasil perhitungan koefisien determinasi $\left(\mathrm{R}^{2}\right)$ diperoleh persentase sumbangan variabel independen yaitu tingkat pendidikan orangtua $\left(\mathrm{X}_{1}\right)$, penghasilan orangtua $\left(\mathrm{X}_{2}\right)$, dan minat belajar mahasiswa $\left(\mathrm{X}_{3}\right)$ berpengaruh terhadap variabel dependen yaitu prestasi belajar mahasiswa (Y) adalah sebesar $68,2 \%$ yang berarti tingkat pendidikan orangtua $\left(\mathrm{X}_{1}\right)$, penghasilan orangtua $\left(\mathrm{X}_{2}\right)$, dan minat belajar mahasiswa $\left(\mathrm{X}_{3}\right)$ dapat menjelaskan prestasi belajar mahasiswa (Y) dan sisanya yaitu sebesar 31,8\% dijelaskan oleh variabel lain yang tidak dikaji dalam penelitian ini.

6.

\section{SARAN}

Berdasarkan pengamatan peneliti selama melaksanakan penelitian pada Mahasiswa Jurusan Manajemen Fakultas Ekonomi Stambuk 2014 Universitas HKBP Nommensen, peneliti memberikan saran sebagai berikut:

1. Mahasiswa diharapkan mampu menggunakan fasilitas yang disediakan orangtua dengan semaksimal mungkin sehingga mampu mengembangkan kemampuan intelektual dan mampu meningkatkan prestasi belajar mahasiswa. Juga mahasiswa mampu membiasakan diri untuk disiplin dalam hal meningkatkan minat belajar, baik itu menyangkut waktu belajar, pengumpulan tugas, membaca buku dan lain-lain.

2. Bagi instansi pendidikan terkhusus Universitas HKBP Nommensen diharapkan mampu melengkapi fasilitas mahasiswa yang mendukung proses pembelajaran mahasiswa, serta mengadakan berbagai kegiatan-kegiatan perkuliahan yang mampu menarik minat belajar mahasiswa. . 
Bagi peneliti lain, diharapkan melakukan penelitian tentang variabel lain yang mempengaruhi prestasi belajar mahasiswa.

\section{REFERENSI}

Ahmadi, Abu. 2007. Sosiologi Pendidikan Jakarta: PT Rineka Cipta.

Arikunto, Suharsimi. 2013. Prosedur Penelitian Suatu Pendekatan Praktik. Jakarta: PT Rineka cipta.

Danim, Sudarman. 2008. Media Komunikasi Pendidikan. Jakarta: PT Bumiaksara.

Departemen Pendidikan Nasional. 2003. Undang-Undang Republik Indonesia No.20 tentang Sistem Pendidikan Nasional. Jakarta: Departemen Pendidikan Nasional Republik Indonesia.

Eryanto, Rika. 2013. Pengaruh Moda Budaya, Tingkat Pendidikan Orangtua, dan Tingkat Pendapatan Orangtua Terhadap Prestasi Akademik pada Mahasiswa Fakultas Ekonomi Universitas Jakatra. Vol.1 No 1 Tahun 2013 ISNN : 23022663 (Diakses Desember 2016).

Hasbullah. 2009. Dasar Dasar Ilmu Pendidikan. Jakarta: PT Raja Grafin Persada.

Ihsan, Fuad. 2011. Dasar - dasar Ilmu Pendidikan. Jakarta: PT Asdi Mahasatya.

Khairani. 2011. Psikologi Belajar. Yogyakarta: Aswaja Pressindo.

Kuncoro, Mudrajat. 2003. Metode Riset untuk Bisnis dan Ekonomi. Jakarta: Erlangga.

Sardiman. 2011. Interaksi dan Motivasi Belajar Mengajar. Jakarta: PT. Raja Grafindo Persada.

Slameto. 2010. Belajar dan Faktor-faktor yang Mempengaruhinya. Jakarta: Rineka Cipta.

Sugiyono. 2004. Metode Penelitian Bisnis. Bandung: Alfabeta.

\footnotetext{
. 2016. Metode Penelitian Pendidikan Pendekatan Kuantitatif, dan Kulaitatif. Bandung: Alfabeta.
}

Suliyanto. 2005. Analisis Data dalam Aplikasi Pemasaran. Bogor: Ghalia Indonesia.

$\begin{array}{ccc}\text { Suryosubroto. } & 2010 . & \text { Dasar-dasar } \\ \text { Kependidikan. Jakarta: Rineka Cipta. }\end{array}$
NIAGAWAN Vol 7 No 1 Maret 2018

Syah. 2007. Psikologi Pendidikan Dengan Pendekatan Baru. Bandung: Remaja Posdakarya.

Toto, Ruhimat, dkk. 2011. Kurikulum dan Pembelajaran. Jakarta: Rajawali Press.

Winkel. 2011. Psikologi Pendidikan dan Evaluasi Belajar. Jakarta : Kencana.

Willis. 2011. Konseling Keluarga ( Family Counseling ). Bandung : Alfabeta. 